\title{
ЮБИЛЕЙНЫЕ ДАТЫ
}

УДК 929

\author{
Н. П. Кузнецова, И. Пардон, М. Пардон
}

\section{СЕРГЕЙ ИВАНОВИЧ ТЮЛЬПАНОВ: К 115-ЛЕТИЮ СО ДНЯ РОЖДЕНИЯ}

Сергей Иванович Тюльпанов - выдающийся ученый, гражданин, дипломат, воин, ровесник XX века, человек удивительной судьбы. Статья представляет собой совместную работу Н.П. Кузнецовой - одной из последних аспиранток С. И. Тюльпанова и Инге и Михаель Пардон - немецких авторов проекта (будущей книги) «Сергей Иванович Тюльпанов - политический портрет», основанного на архивных материалах, собранных в России и Германии. Немецкие коллеги особо останавливаются на работе Тюльпанова в послевоенной Германии в Управлении информации СВАГ, показывают его роль как одного из основоположников российсконемецкой дружбы и сотрудничества, ставшего легендой и Восточной, и Западной Германии.

Значительная часть статьи посвящена Тюльпанову как Учителю, крупному ученому-идеологу, создателю кафедры экономики современного капитализма, занимавшемуся общественной наукой - не только экономической, но и исторической, философской и т. д. Несмотря на то что Тюльпанов был привержен «марксистско-ленинской теории общественного развития», он стремился придать ей живое дыхание, уйти от догматизма застывших идеологических норм и в этом формате воспитывать своих учеников, бравших с него пример нравственности и профессионализма. Библиогр. 26 назв. Ил. 3.

Ключевые слова: Управление информации, Советская военная администрация в Германии (СВАГ), ГДР, кафедра экономики современного капитализма, научно-преподавательская и идеологическая деятельность.

Наталия Петровна КУЗНЕЦОВА - доктор экономических наук, профессор, СанктПетербургский государственный университет, Российская Федерация, 199034, Санкт-Петербург, Университетская наб., 7-9; nataliakuz2010@yandex.ru

Ингеборг ПАРДОН - кандидат исторических наук, дипломированный преподаватель, архивариус, директор берлинского Центра иностранных языков «Диалогика», D-12681 Берлин, Кюренцерштрассе, 44; info@dialogica-institut.de

Михаель ПАРДОН - доктор технических наук, инженер, директор инженерной фирмы «Утекон», D-12681, Берлин, Кюренцерштрассе, 44; utecon206@gmx.de

Natalia P. KUZNETSOVA - Doctor of Economics, Professor, St. Petersburg State University, 7-9, Universitetskaya nab., St. Petersburg, 199034, Russian Federation; nataliakuz2010@yandex.ru

Ingeborg PARDON - PhD in History, qualified tutor, archivist, Director of the Berlin Center for foreign languages “Dialogic”. 44 Kurencer Str., Berlin, D-12681, Germany; info@dialogica-institut.de

Michael PARDON - Dr.-Ing., Engineer, Director of the engineering firm Utecon. 44 Kurencer Str., Berlin, D-12681, Germany; utecon206@gmx.de

(c) Санкт-Петербургский государственный университет, 2017 


\section{Pardon, M. Pardon, N. P. Kuznetsova}

\section{SERGEY IVANOVITCH TYULPANOV: THE 115 ANNIVERSARY OF BIRTHDAY}

Sergej Ivanovitch Tjulpanov - the outstanding scientist, citizen, diplomat, warrior, born at the beginning of the twentieth century, a man of amazing destiny that was shaped and defined by the time and country he lived in. The paper is a result of collaboration between N.P. Kuznetsova - one the last S. I. Tyulpanov's post-graduate student and Ingeborg and Michael Pardon - German authors of the «Sergej Tjulpanov - the political portrait» project (and future book) based on enormous volume of archive materials collected in Russia and Germany. German colleagues particularly dwell on the Tyulpanov's activities in the post-war Germany in the Department of Information (SMAD). After the World War II he happened to be one of the founders of the Russian-German friendship and cooperation, who has become a legend of Eastern and Western Germany. The essential part of the paper is dedicated to Tjulpanov as the Teacher and distinguished scientist-ideologist, the founder of the Modern Capitalism Economy Department. Studying social science including economics, history, philosophy, etc. he was committed to what was called "Marxist-Leninist theory of social development", trying to get reed of frozen ideological norms and in this format to offload from dogmatism educating students, who took his example in the invisible moral status "overflow" into the professional activityand vice versa. Refs 26. Figs 3.

Keywords: Department of information, Soviet military administration in Germany (SMAD), DDR, modern capitalism economy department, scientific, teaching and ideological activities.

\section{Введение}

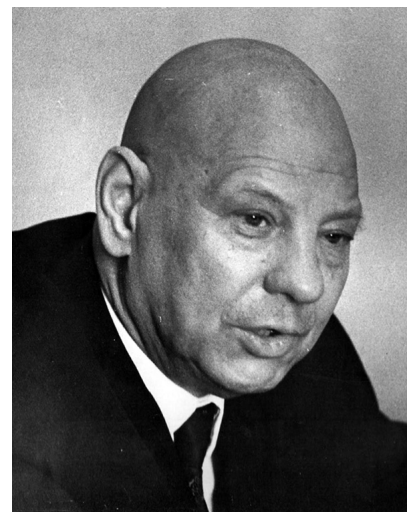

3 октября 2016 г. - памятная дата в истории СанктПетербургского государственного университета и экономического факультета. 115 лет тому назад родился Сергей Иванович Тюльпанов - выдающийся ученый, гражданин, дипломат, воин. Тюльпановым может гордиться не только Университет, но и наша Отчизна, так как он оставил заметный след в мировой науке, в послевоенной отечественной и европейской политической истории. Когда 16 февраля 1984 г. его не стало, один из наших немецких друзей сказал на гражданской панихиде: «В ГДР по такому случаю был бы объявлен национальный траур».

Имя и деятельность С.И. Тюльпанова до сих помнят и чтят не только в восточных, но и в западных землях Германии. В Музее битвы за Берлин на Зееловских высотах, в Музее в Карлсхорсте сохранились фотографии и воспоминания о нем. В 1999 г. профессор В. С. Торкановский читал лекции в Дрезнер Банке во Франкфурте-на-Майне и был поражен, когда спустя 50 лет после работы Сергея Ивановича в Германии услышал от высокопоставленных банковских работников хвалебные отзывы о «русском генерале Тюльпанове» [Торкановский, 2012, c. 3-6].

Вместе с тем на Западе сегодня культивируется махровая русофобия с привкусом реваншистских амбиций. Подогревается старая ненависть, и становится модным пренебрежение ко всему русскому. Многие западные и некоторые русские историки выступили в конце 80-х и начале 90-х годов ХХ в. с искажением фактов, несправедливой оценкой и откровенной ложью о роли и действиях Советской военной администрации и советских войск в послевоенной Германии. Подготовка к публикации в Германии немецкими соавторами настоящей статьи книги «Поли- 
тический портрет С. И. Тюльпанова» (“Sergej Iwanowitsch Tjulpanow - ein politisches Porträt”) призвана противостоять этой опасной тенденции.

С.И. Тюльпанов, будучи гражданином своей страны, прошел тяжелый путь испытаний, участвуя в кровопролитных войнах - Гражданской и Отечественной, сумел пережить годы репрессий 30-х и и 40-х годов прошлого века, был идеологом построения социализма как в Советской России, так и в Восточной Европе. «Сергей Иванович Тюльпанов - ровесник XX века, человек удивительной судьбы. Ее формировало и определяло время. Но в неменьшей степени - он сам, его стремления и воля, представления о сущем и должном, которые хотя и изменялись под влиянием событий, но не отклонялись от нравственного стержня» [Шейнис, 1991, c.132]. Чем дальше мы находимся по оси времени от событий XX в., тем больше восхищаемся такими людьми, как Сергей Иванович Тюльпанов, обыкновенным чудом его судьбы и времени, которое он прожил достойно и талантливо.

\section{Начало пути}

Сергей Иванович Тюльпанов родился 3 октября1901 г. Его отец, Иван Алексеевич, был землемером, окончил лесную школу при Петровской академии, учился за границей, знал иностранные языки и управлял лесными угодьями Строгановых в Псковской губернии. Мать, Эльза Вильгельмовна, была из латышской семьи. Судьба родителей С. И. Тюльпанова сложилась трагически - в 1938 г. был репрессирован отец, а в 1940 г. - мать [Загадка полковника Сергея Тюльпанова. Пробелы анкетных данных...].

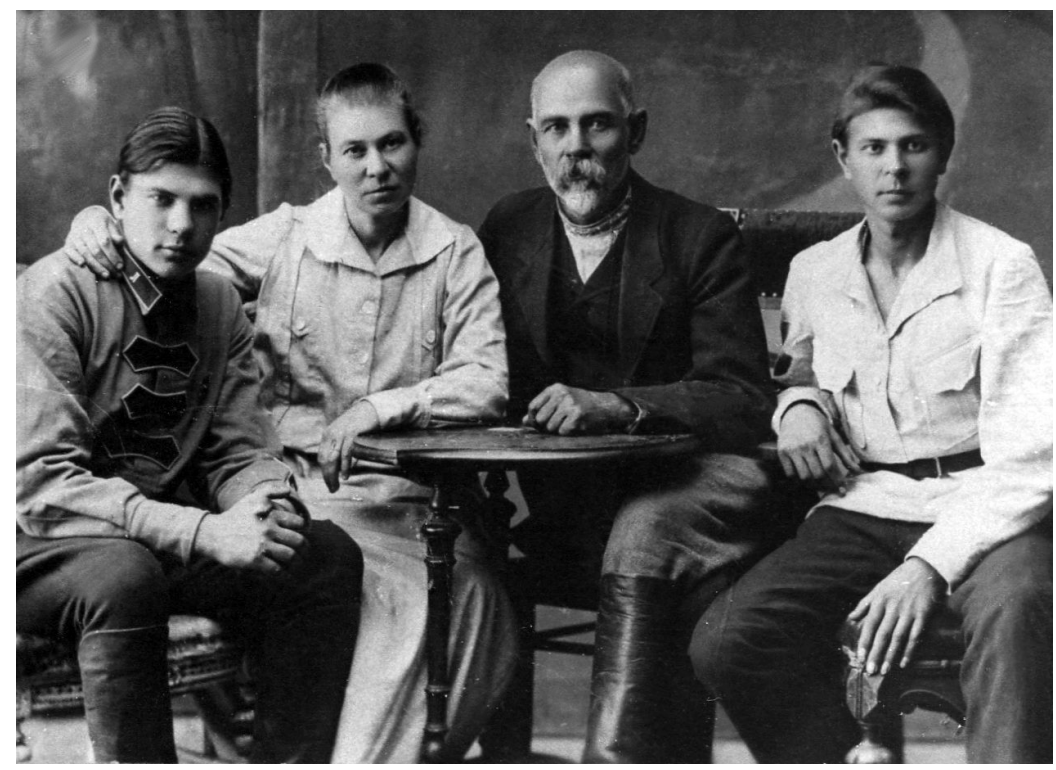

Семья Тюльпановых в 1920 г. (из семейного архива). Крайний слева красноармеец Тюльпанов

Сергей Иванович Тюльпанов проходил службу в рядах РККА с 1919 по 1925 г. и с 1941 по 1956 г. Член ВКП(б) с 1927 г. В 1919-1923 гг. - помощник шофера, крас- 
ноармеец, делопроизводитель, бухгалтер, начальник финансово экономического отдела 10-й стрелковой дивизии 7-й Туркестанской бригады. В 1923-1924 гг. - делопроизводитель окружного хозяйственного управления Ленинградского военного округа. В 1925-1929 гг. - студент Ленинградского педагогического института им. А.И. Герцена. В 1929 г. окончил Военно-политическую академию в Ленинграде, а в 1930 г. (экстерном) - общественно-экономическое отделение Ленинградского государственного педагогического института им. А.И.Герцена. В 1927-1931 гг. преподаватель Артиллерийской технической военной школы и Педагогического института им. А. И. Герцена, в 1931-1937 гг. - старший преподаватель кафедры политической экономии Военно-политической академии им. В. И. Ленина в Ленинграде.

В период «большого террора» 1937-1938 гг., попав в поле зрения репрессивных органов, Тюльпанов никого не предупредил и уехал в деревню, где находился с мая по сентябрь 1938 г. Возвратившись осенью в Ленинград, он устроился учеником слесаря на небольшой завод. За свое несанкционированное исчезновение он получил партийный выговор, а затем вновь стал преподавать политэкономию, сначала в Технологическом институте, затем в Лесотехнической академии. В 1937-1940 гг. он был заведующим кафедрой политической экономии, профессором Лесотехнической академии им. С. М. Кирова; в 1938-1941 гг. - заведующим кафедрой политической экономии ленинградских Ленинских курсов при ЦК ВКП(б) [История факультета в лицах...]. В довоенные годы им было опубликовано много научных работ, учебников, способствовавших становлению молодой советской экономической науки. С.И. Тюльпанов также являлся редактором ряда фундаментальных изданий, таких как многотомная «История фабрик и заводов Ленинграда». В 1939-1940 гг. вместе с профессором А.А. Вознесенским он был инициатором создания экономического факультета Ленинградского государственного университета [Семенов, 2010].

\section{Великая Отечественная война и Советская военная администрация в Германии (СВАГ)}

Довоенная биография Сергея Ивановича предопределила его карьеру в военные годы. С первых дней Великой Отечественной войны С. И. Тюльпанов участвовал в боях с фашистскими захватчиками на Ленинградском фронте, под Лугой, в качестве комиссара разведотдела 42-й армии.

В сентябре 1941 г. полковой комиссар С. И. Тюльпанов был назначен начальником отдела по работе среди войск противника Политуправления Ленинградского фронта. Он постоянно информировал руководство блокадного города (А.А. Жданова, А. А. Кузнецова) о морально-политическом состоянии немецких воинских частей. В самое тяжелое время блокады, в декабре 1941 г., С. И. Тюльпанов по заданию командования фронта неоднократно выступал по радио и в Центральном лектории (Литейный проспект, д. 42) перед измученными голодом и холодом людьми с призывами к стойкости, убеждал их в неизбежности нашей Победы. Выступления уверенного в себе, твердого, мужественного человека, его оптимизм незабываемы они свидетельствовали о том, как много может сделать один человек, чтобы поднять дух, укрепить волю и продлить жизнь других людей [Торкановский, 2012, с. 5].

В 1942-1945 гг. С.И.Тюльпанов воевал на Сталинградском и 4-м Украинском фронтах. К тому времени относятся его первые контакты с ведущими деятелями 


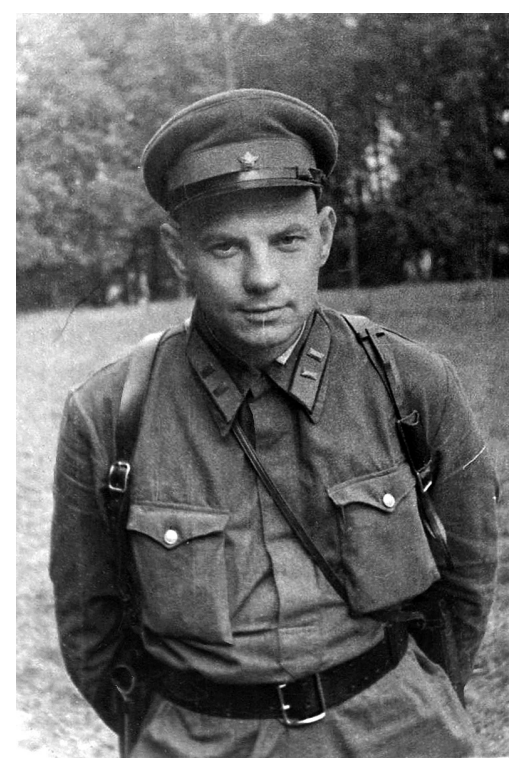

Политкомиссар Тюльпанов. Ленинград 1941 г. (Семейный архив)

международного рабочего движения, немецкими антифашистами (В.Пик, В. Ульбрихт). С. И. Тюльпанов много сил приложил к тому, чтобы создать среди немецких военнопленных просоветские организации солдат и офицеров. Таким образом, его карьера военных лет связана с политработой среди населения и войск противника. В годы войны С.И. Тюльпанов занимает должности: в 1941 г. - начальника 7-го отделения Политического отдела 42-й армии; в 1941-1942 г. - начальника 7-го Отдела Политического управления Ленинградского фронта; в 1942-1945 гг. - начальника 7-го Отдела Политического управления Юго-Западного, Сталинградского, Южного и 4-го Украинского фронтов [История политической экономии. Тюльпанов....]. К концу войны в августе 1945 г. полковник С. И. Тюльпанов, как один из лучших начальников 7-х отделов ряда фронтов, был принят в Берлине маршалом Жуковым, который в своих мемуарах одобрительно отзывался о его деятельности. По окончании войны Тюльпанов был назначен на пост начальника 7-го Отдела Политического управления Группы советских оккупационных войск в Германии.

С 5 октября 1945 г. по 18 сентября 1949 г. Сергей Иванович Тюльпанов занимал одну из важнейших должностей в созданной по окончании Великой Отечественной войны Советской военной администрации в Германии (СВАГ) - начальника Управления пропаганды (позднее переименовано в Управления информации). Он был решительным сторонником Вильгельма Пика, Отто Гротеволя, Вальтера Ульбрихта и внимательно следил за деятельностью новой Социалистической единой партии Германии, предполагая, что она занимает ведущее место в политической структуре ГДР.

\section{Управление пропаганды СВАГ и становление послевоенной Германии}

Возглавив 5 октября 1945 г. Управление пропаганды СВАГ, С.И.Тюльпанов сразу подпал под контроль нескольких высоких московских инстанций [СВАГ в Германии..., 2009]. Реально Тюльпанов и его ведомство были подчинены Отделу внешней политики ЦК ВКП (б) во главе с М.А.Сусловым. Именно в этом отделе подготавливались значимая информация, проекты постановлений и директив, которые затем передавались наверх. Начиная с апреля 1946 г., т. е. времени назначения Суслова заведующим Отделом внешней политики (с декабря 1945 по апрель 1946 г. - Отдел международной информации), складывается довольно устойчивая цепочка связи и передачи информации: Тюльпанов - Суслов [СВАГ. Управление пропаганды..., 1994].

С приходом Суслова Отдел внешней политики заметно расширил свои функции, прежде всего, за счет предоставления отделу права на расстановку кадров, 
в том числе в МИД СССР. У отдела появляется и новый аспект деятельности «оперативная работа», которая предусматривала наблюдение за методами пропаганды, изучение кадров в различных советских организациях за рубежом и др.

Если за Тюльпановым стояли не просто «главпуровцы», но и фронтовики, то за политсоветником В. С. Семеновым ${ }^{1}-$ чиновники МИД. Вспышки борьбы МИД (а значит, и правительства) и Отдела внешней политики (ЦК) давали о себе знать в Берлине.

Все кадровые вопросы по СВАГ решались в Управлении кадров ЦК, подчиненном члену Политбюро и секретарю ЦК А. А. Кузнецову, и Государственной штатной комиссии при правительстве, возглавляемой Л. 3. Мехлисом ${ }^{2}$. Устойчивость положения Тюльпанова на протяжении четырех послевоенных лет зависела именно от этих двух человек. На заседаниях Секретариата ЦК ВКП(б) сходились и сталкивались интересы всех перечисленных ведомств.

История отношений С.И. Тюльпанова и В.С.Семенова, назначенного с 15 мая 1946 г. политсоветником Главноначальствующего СВАГ, заслуживает особого внимания. С Семеновым Тюльпанов пытался держаться корректно, но твердо. К тому же к моменту назначения Семенова у Тюльпанова образовался огромный политический опыт и завидная популярность в советской зоне оккупации. Немецкие коллеги порой именно Тюльпанова воспринимали как «всемогущего» политсоветника. В принципе и Семенов (до 1948 г.) открыто не вмешивался в дела Тюльпанова в зоне. Очевидное столкновение Семенова и Тюльпанова началось лишь после того, когда участь последнего в Москве была уже практически решена. В марте 1949 г. на собрании партийного актива СВАГ оба руководителя публично продемонстрировали свои разногласия. 18 сентября 1949 г. Секретариат ЦК принял решение об отзыве Тюльпанова из Германии [РГАСПИ. Л.181-182]. Семенов мог праздновать окончательную победу над своим оппонентом - 5 ноября 1949 г. Политбюро приняло решение о создании Советской контрольной комиссии в ГДР и переводе тюльпановского Управления информации в аппарат политсоветника [РГАСПИ. Л. 322, 328].

Изучение жизнедеятельности Тюльпанова позволяет рассмотреть множество различных связей внутри СВАГ и вне ее. Постоянные конфликты вокруг личности и самостоятельной политической линии Тюльпанова показывают, что в Москве имелись различные, конкурирующие друг с другом представления о решающем для Германии пути развития. Как это ни парадоксально, нечеткость представлений

\footnotetext{
${ }^{1}$ Семенов Владимир Семенович (1911-1992), советский дипломат, партийный деятель. Родился в с. Краснослободское (ныне ст. Иноковка) Кирсановского у. Тамбовской губ. Член ВКП(б) с 1938 г. Окончил Московский институт истории, философии и литературы (МИФЛИ) (1937). С 1939 г. на дипломатической работе в Литве, Германии, Швеции. В 1945-1953 гг. политсоветник при Главноначальствующем СВАГ, в последующем - при председателе Советской контрольной комиссии в Германии. В 1953-1954 гг. Верховный комиссар СССР в Германии, Чрезвычайный и Полномочный Посол СССР в ГДР. В 1954-1955 гг. член Коллегии, зав. отделом МИД СССР. С марта 1955 г. зам. министра иностранных дел СССР. Участник многих международных конференций и совещаний. С ноября 1969 г. руководитель делегации СССР на переговорах с США по ограничению стратегических вооружений. Член Центральной ревизионной комиссии КПСС в 1952-1966 гг., кандидат в члены ЦК КПСС с 1966 г. Награжден двумя орденами Ленина, орденом Октябрьской Революции, четырьмя другими орденами, а также медалями. Умер в г. Кёльне (из личного архива Е. В. Семеновой).

2 Документы: Государственный архив Российской Федерации (ГАРФ) и Российский государственный архив социально-политической истории (РГАСПИ) о деятельности Советской военной администрации в Германии (СВАГ). 1945-1949. (Бюллетень рассекреченных документов федеральных государственных архивов).
} 
о будущем Германии, противоречивость указаний сверху, неунифицированность прохождения сигналов из Кремля создавали возможность применения различных вариантов советской модели Восточной Германии, а следовательно, и решения германского вопроса. Однако расформирование СВАГ и отзыв Тюльпанова означали завершение целой эпохи, так как после этого началось резкое ограничение возможностей свободного выбора модели развития Германии. Возглавившие в 1949 г. Советскую контрольную комиссию в Германии маршал В.И. Чуйков и политсоветник В.С.Семенов в 1950-1952 гг. резко сузили возможности руководителей молодой ГДР апеллировать к тем или иным структурам и разным мнениям политических лидеров в Москве. В этом отношении период деятельности СВАГ представляется временем выбора и надежд на иные сценарии развития событий в Германии и послевоенных советско-немецких отношений. Анализируя этот период, можно отметить, что на жизненном пути Тюльпанова постоянно возникали коллизии также и потому, что по складу личности он всегда был и ученым-аналитиком, и активным преобразователем окружающего мира. Здесь можно вспомнить известный одиннадцатый тезис К. Маркса о Фейербахе: «Философы лишь различным образом объясняли мир, но дело заключается в том, чтобы изменить его». Инструментом изменения мира была и остается политика, и Тюльпанов, несомненно, стал бы профессиональным политиком, живи он в иное время [Шейнис, 2001; 2016].

Аспиранты и молодые преподаватели кафедры экономики современного капитализма 1960-1970-х годов обучения осознавали, что Тюльпанов, как лицо высшей номенклатуры СВАГ, хорошо знает реальную борьбу политиков и дипломатов вокруг Сталина. Общаясь с ним, можно было приблизиться к пониманию механизмов принятия политических решений, в том числе по поводу послевоенного будущего Германии. Пользуясь атмосферой открытости Тюльпанова и преподавателей, молодежь прямо на заседаниях кафедры, посвященных экономике и политике ГДР-ФРГ, задавала острые (по тем временам) вопросы о деятельности Сергея Ивановича: кто определял советскую политику в зоне советского влияния; находился ли С.И. Тюльпанов в центре принятия политических решений в Восточной Европе вообще и Восточной Германии в частности; каковы были модели, формы и темпы применения советского сценария развития в Восточной Германии и т. д.? Надо сказать, что Сергей Иванович то ли отшучивался, уходя от обсуждения, то ли давал неполные ответы на эти вопросы, обещая своим близким, коллегам и ученикам написать воспоминания о немецком периоде своей жизни. Чувствуя жажду правды, справедливости и неподдельный интерес своих учеников, Тюльпанов время от времени публиковал политические статьи, рассказы о встречах с деятелями культуры. Сергей Иванович частично «раскрылся» только в 1980-х годах, написав свои воспоминания уже к концу жизни. По-русски ему удалось опубликовать лишь значительно сокращенные цензурой клочки этих воспоминаний [Тюльпанов, 1984]. В 1986 г. в ГДР, уже после смерти Тюльпанова ${ }^{3}$, С. Дернберг издал его воспоминания [Tjulpanov, 1986]. Но, по оценке специалистов, эти воспоминания неполны, в них отсутствуют собственные авторские оценки своей роли в «высокой дипломатии» послевоенной Европы и Германии. Сборник архивных документов «СВАГ. Управление пропаганды (информации) и С.И.Тюльпанов» под ред. Б.Бонвеча, Г.Бор-

${ }^{3}$ Сергей Иванович Тюльпанов скончался 16 февраля 1984 г. в возрасте 82 лет. Похоронен в Ленинграде на Серафимовском кладбище. 
дюгова, Н.Неймарка был опубликован в 1994 г. Он содержит интересные, в том числе личные, документы. Однако эти документы не снабжены основательными комментариями, поэтому сборник грешит искажениями фактов жизнедеятельности и характерных черт крупного организатора и честного, убежденного идейного борца за высокие идеалы, каким был Сергей Иванович. Только нынче из обрывков «рассеянного знания» к нам приходит понимание (да и то неполное) биографии и личности Сергея Ивановича Тюльпанова, его роли в европейской дипломатии, в строительстве социализма в ГДР и в других странах народной демократии.

В деятельности Тюльпанова в Германии 1945-1949 гг. просматриваются три периода, которые отражают ряд внутренних и внешних противоречий и в Москве, и в Берлине. Послевоенные события жизни Тюльпанова помогают раскрыть те цепочки, которые связывали СВАГ с Москвой, увидеть реальную борьбу и в Москве, и в оккупационной зоне по поводу будущего Германии [Загадка полковника Сергея Тюльпанова...].

Первый период (октябрь 1945 - декабрь 1946 г.) был связан с ростом его авторитета и влияния, проявлением значительной самостоятельности в разработке таких вопросов, как тактика слияния коммунистов и социал-демократов в советской зоне оккупации, установление контроля над либеральными и христианскими демократами, проведение выборов в сентябре-октябре 1946 г. В те годы «Управление Тюльпанова», как его тогда называли, было важной, для немцев наиболее известной, составной частью СВАГ. Не ограничиваясь цензурой печати и радио, оно осуществляло контроль и помощь политическим партиям и общественным (профсоюзным, женским, молодежным) организациям, занималось пропагандой политических и экономических преобразований, развития науки, культуры, искусства [Басистов, 2012, с. 7]. Под руководством С. И. Тюльпанова в Германии началось восстановление многопартийной политической жизни, многих демократических институтов. Кроме аппарата в Лихтенберге, в его структуру вписывались также 6 земельных (провинциальных) и 5 городских отделов, 18 окружных отделений, 146 инструкторов районных комендатур. К 480 высококвалифицированным экспертам надо прибавить еще 700-800 вспомогательных сотрудников. Весьма непростыми были отношения между органами военного и мидовского подчинения. Все более обострялись отношения СВАГ с администрациями западных союзников в Контрольном совете и Союзной комендатуре Берлина [Драбкин, 2001, с. 10].

Второй период (январь 1947 - декабрь 1948 г.) ознаменовался серьезными ограничениями деятельности Тюльпанова со стороны чиновников из Москвы. Он был вынужден действовать осторожно и сдержанно. Постоянная угроза снятия с должности (в декабре 1946 - январе 1947 г., затем в апреле 1947 г., апреле 1948 г., октябре-декабре 1948 г.) заставляла его нервничать, отвлекаться на выяснение настроений в Москве. Кажется, что Тюльпанов осознает смену приоритетов в международной политике, которая после речи Черчилля в Фултоне в 1946 г. была направлена на раскол мира на два противоборствующих «лагеря». На первом совещании Коминформа в сентябре 1947 г. ${ }^{4}$ была принята сталинская установка относительно социалистического пути развития восточноевропейских стран. Именно документы

4 22-28 сентября 1947 г. по инициативе советского руководства и И. В. Сталина в ШклярскаПорембе близ Варшавы состоялось совещание девяти компартий, вошедшее в историю как первое совещание Коммунистического информационного бюро [Гибианский, 1998]. 
Коминформа легли в основу политико-экономического развития стран «народной демократии», включая и ГДР. Все это фиксируется лидерами СЕПГ и других партий, изменяется их отношение к Тюльпанову и возглавляемому им Управлению СВАГ. Во второй период просматривается явная взаимосвязь личной судьбы Тюльпанова и противоречий между державами-победительницами относительно будущего Германии. Общая установка этих государств, принятая в Потсдаме, трактовалась и реализовывалась по-разному. Курс СССР на осуществление в советской зоне антифашистско-демократических преобразований был ориентирован на построение социализма советского типа и соответствовал представлениям работников СВАГ, включая Тюльпанова, что усложняло отношения Управления информации СВАГ с руководством буржуазных партий [Драбкин, 2001, с. 10]. Именно последним обстоятельством и объясняется проводимый Тюльпановым курс на образование в ГДР многопартийной системы, что послужило одним из факторов обострения отношений Тюльпанова с Сусловым, который в соответствии с документами Коминформа был убежден в необходимости построения однопартийной модели развития ГДР 5 .

Третий период (январь-август 1949 г.) связан с потерей политического влияния Тюльпанова, отзывом его в Москву и снятием с должности руководителя Управления информации СВАГ, деятельность которого свернули летом 1949 г. Сложность положения Тюльпанова в третий период усугублялась многократными «проверками» московских комиссий, после проведения которых несколько раз предлагалось его «сместить», не в последнюю очередь за независимость суждений и самостоятельность принятия политических и дипломатических решений. Однако, несмотря на то что тучи над головой Тюльпанова сгущались, 11 мая 1949 г. ему присвоили звание генерал-майора, и именно в этом звании весной 1949 г. его отправили на конференцию министров иностранных дел в Париж.

Последним толчком в деле смещения Тюльпанова выступил «компрометирующий» материал, который руководитель службы контрразведки в СВАГ генераллейтенант Н.К.Ковальчук в августе 1949 г. передал министру государственной безопасности В.С.Абакумову. Якобы Тюльпанов знал о предательстве сотрудника руководимого им управления, но не передал его в руки органов безопасности. Кроме того, Тюльпанову вменялось в вину осуждение его родителей за шпионаж. Абакумов просил Маленкова отозвать Тюльпанова из Германии. Двумя днями позже Суслов распорядился, чтобы Главное политическое управление под служебным предлогом вызвало Тюльпанова в Москву для последующего допроса относительно предъявленных обвинений.

25 августа Тюльпанов вылетел в Москву, где его сразу же поместили в военный санаторий, практически под домашний арест. Там он и ждал решения своей участи. 18 сентября 1949 г. Секретариат ЦК принял решение об отзыве Тюльпанова из Германии [Загадка полковника Сергея Тюльпанова. Московские коридоры власти...].

\footnotetext{
5 Отдел внешней политики ЦК ВКП(б) по заданию советского руководства составил в августе - начале сентября 1947 г. информационно-аналитические записки почти о каждой существовавшей тогда компартии. Главные критерии их оценки выражались в степени сосредоточения власти в руках коммунистов, оттеснения, подчинения или фактической ликвидации других политических партий, изменения всей государственной структуры в соответствии с этими целями, осуществления национализации, проведения аграрной реформы в деревне, развития кооперации под контролем компартии. Важнейшим критерием была также степень ориентированности внешней политики на Советский Союз [Протокол первого совещания..., 1998] .
} 
Однако, несмотря на то что он был лишен возможности вернуться в Германию из отпуска, учитывая военные, политические, административно-дипломатические связи, роль в построении социализма в ГДР и тот факт, что Сергея Ивановича знали не только немецкие антифашисты, эмигранты из Коминтерна, возвратившиеся на родину, но и люди нового поколения [Басистов, 2012, с. 8], в 1949 г. Тюльпанова уже в звании контр-адмирала откомандировали на должность заместителя руководителя кафедры политической экономии Военно-морской академии в Ленинграде. Позднее он становится начальником кафедры политической экономии Военной академии связи им. С. М. Буденного [Электронный каталог в лицах..., 2016].

\section{Научная деятельность}

После ухода с воинской службы ${ }^{6}$ С. И. Тюльпанов вернулся к научно-педагогической работе, связал свою жизнь с наукой, продолжая международную деятельность уже в «мире академического знания». А. Д. Александров, ректор ЛГУ в 1950-е годы, услышал блестящее выступление Тюльпанова на одном из городских совещаний и пригласил его на должность проректора ЛГУ. С.И. Тюльпанов был одаренным организатором, но предложенная ему работа могла ограничить реализацию его талантов в сфере науки. В 1957 г. он становится заведующим созданной им кафедры экономики современного капитализма, которую возглавляет в течение 20 лет. Кафедра формировалась и развивалась как уникальный научный коллектив, объединенный передовыми идеями своего лидера. На кафедре господствовала творческая атмосфера глубокого научного анализа, поиска нового, неординарного. С.И.Тюльпанов был выдающимся организатором науки, заботливым воспитателем $^{7}$ научных кадров в полном смысле этого слова. Его научный и моральный авторитет был очень велик. Научное любопытство, интеллектуальная свобода, мощное историко-экономическое и философское мышление, моральная ответственность предопределили оригинальность и масштаб творческой мысли Тюльпанова, ставшего в СССР одним из основателей теории мировой экономики и международных экономических отношений. Его концепции оказали огромное влияние на восточно-европейскую и отечественную экономическую науку и на формирование современной ментальности ученых - исследователей новых, зачастую революционных, явлений и процессов современного мира.

Руководимая им кафедра стала одним из ведущих в стране центров передовой экономической мысли. Именно кафедра организовала в 1960-1970-е годы проведение в Ленинграде многих научных конференций по проблемам развивающихся стран, в которых участвовали ученые из разных государств Азии, Африки и Латин-

${ }^{6}$ С. И. Тюльпанов вышел в отставку в 1956 г.

7 Показательна в этом отношении судьба немецких соавторов настоящей статьи. Инге познакомилась с Сергеем Ивановичем в 1969 г. во время его визита в ее родной университет в г. Росток, когда проф. Тюльпанов предложил ей свое научное руководство по аспирантуре. В августе 1970 г. Министерство высшего образования ГДР направило Инге в аспирантуру МГУ в Советский Союз, хотя министерским чиновникам наверняка было известно, что Тюльпанов преподает в ЛГУ, а ее муж учится в Военной академии связи в Ленинграде. Сергей Иванович очень рассердился и по своим каналам в Москве организовал перевод Инге из МГУ на кафедру новой и новейшей истории ЛГУ, воссоединив молодую семью и создав идеальные условия для совместной работы и общения, показав пример живого человеческого участия в судьбе молодой немецкой пары. 
ской Америки, а также из США и стран Европы. На кафедре были подготовлены сотни квалифицированных экономистов не только для России, но и для европейских и развивающихся стран. Большое значение для преподавателей и студентов имело то, что С. И. Тюльпанов установил связи с академическими институтами Москвы, европейскими университетами. Студенты, дипломанты и аспиранты кафедры (среди которых - не только экономисты, но и лингвисты, философы, историки, востоковеды, т. е. люди без базового образования ${ }^{8}$ ) имели возможность пройти полугодовую преддипломную и аспирантскую практику в Москве, где слушали спецкурсы в Московском университете, Институте мировой экономики и международных отношений, Институте США и Канады, Институте Азии, Африки и Латинской Америки, пользовались библиотеками этих и иных центров науки и образования. Большое значение имели первые зарубежные стажировки преподавателей и поездки студентов в страны Восточной, а потом и Западной Европы [Скляр, 2012, c. 9].

С.И. Тюльпанов не ограничивал свою деятельность только руководством кафедрой. Долгие годы он был членом редколлегии журналов «Мировая экономика и международные экономические отношения», «Вестник Ленинградского университета» (серия «Философия, экономика, право»), руководил в Ленинграде обществом Советско-немецкой дружбы, а также филиалом Института Африки АН СССР. Он выступал с лекциями в разных странах, особенно в Германии, где его приветствовали с особым почетом. Посещавшие Ленинград представители многочисленных делегаций из ГДР стремились встретиться с ним. Он вел большую работу во влиятельном Обществе германо-советской дружбы. Начиная с 1965 г. Тюльпанов неоднократно посещал ГДР и дважды - ФРГ с общественными делегациями, не говоря о гостевых визитах по личным приглашениям друзей.

Одним из первых Тюльпанов стал анализировать модели рыночной экономики в развитых и развивающихся странах, написав более 200 монографий и статей, посвященных не исследовавшимся ранее проблемам. Он является одним из основателей нового раздела политической экономии, в котором исследуются социально-экономические и общественно-политические проблемы развивающихся стран [Электронный каталог. Тюльпанов...]. Потребность в создании теории развития этих стран возникла в связи с кризисом и крахом колониальной системы и необходимостью преодоления их экономической и социальной отсталости. Своеобразие внутренних и внешних условий развития бывших колоний потребовало подлинно творческого подхода.

В 1960-е годы прошлого века были изданы основные научные труды С. И. Тюльпанова, посвященные положению дел в экономике и политике стран «третьего мира»: монографии «Колониальная система империализма и ее распад» (1958), «Экономические и политические проблемы новых суверенных государств» (1964) и наиболее известная монография «Очерки политической экономии: развивающиеся страны» (1969), ставшая во многих отношениях одним их ведущих тру-

${ }^{8}$ В развитии научных исследований Сергей Иванович делал ставку прежде всего на молодежь. Аспиранты знакомились с методологией подлинно исследовательского подхода. Не случайно, когда в конце прошлого века произошел отказ от марксистских догм в преподавании экономической науки, воспитанникам кафедры экономики современного капитализма зачастую было легче оказаться в мейнстриме мировой экономической мысли, воспринять новые экономические концепции, поновому преподавать экономическую теорию [Скляр, 2012, с. 10]. 
дов в советской экономической науке тех лет. Издание этой работы усилило известность С. И. Тюльпанова в стране и за ее пределами.

В этих работах С.И. Тюльпанова значительное внимание уделено выяснению места новых суверенных государств в системе мирового капиталистического хозяйства и мерам по преодолению отрицательных последствий международного капиталистического разделения труда. Ученый подробно исследовал влияние мировой социалистической системы на ход борьбы за индустриализацию и изменение колониальной структуры хозяйства этих государств, указывая на социально-экономические перспективы на путях капиталистического и некапиталистического вариантов развития 9 .

Большие достижения С.И.Тюльпанова относятся к области исследования проблем современного капитализма. Его перу принадлежат работы по изучению общего кризиса капитализма, действия основного экономического закона капитализма во второй половине XX века, но особо значим его вклад в теорию государственно-монополистического капитализма. С.И. Тюльпанов рассматривал ГМК как современную систему производственных отношений, а государство - как макроэкономический элемент общественного воспроизводства. В его работе «Актуальные проблемы политической экономии современного капитализма» (в соавторстве с В.Л. Шейнисом) показано, что в период ГМК происходит значительная модификация действия экономических законов капитализма.

В своих исследованиях Тюльпанов доказывал, что действие всеобщего закона капиталистического накопления, законов относительного и абсолютного обнищания рабочего класса и усиления капиталистической эксплуатации, роста органического строения капитала, тенденции нормы прибыли и нормы процента к понижению, по меньшей мере, исторически ограничено, что в XX в. возникают противодействующие факторы их реализации. Труды Тюльпанова по исследованию экономики индустриально развитых стран вызвали большой интерес у специалистов и, будучи переведены на многие иностранные языки, сделали его имя еще более известным мировой научной общественности. Профессор С. И. Тюльпанов - почетный доктор Лейпцигского университета им. К. Маркса, редактор ряда фундаментальных изданий [Тюльпанов, Сергей Иванович...].

В последние годы своей жизни С.И. Тюльпанов много размышлял о положении нашей страны, политике ее руководства. Он видел, что разрыв между теорией и практикой общественной жизни оказался у нас слишком велик, что советская экономика постепенно стагнирует, ослабляются связи с прогрессивной мировой общественностью. Но все это не могло изменить глубокой веры С. И. Тюльпанова в то, что социализм может и должен стать экономической системой социальной справедливости и национального равноправия ${ }^{10}$.

${ }^{9}$ Великолепным примером преемственности и верности школе С.И. Тюльпанова являются работы академика Г. И. Чуфрина по развивающимся государствам и особенно его недавно появившиеся труды по развитию процессов экономической интеграции на постсоветском пространстве (см., напр.: Очерки евразийской интеграции. М.: Весь мир, 2013). Геннадий Илларионович Чуфрин прошел путь от студента (1953-1958), затем аспиранта ЛГУ, защитившего кандидатскую диссертацию (1965), до доктора экономических наук (1981), профессора (1990), член-корреспондента (1994), академика РАН (2016).

10 Материал взят из выступления Н.В.Раскова «Кафедра экономики современного капитализма: уроки Тюльпанова» на секции 6, посвященной 115-летию со дня рождения С. И. Тюльпанова 


\section{С. И. Тюльпанов - Человек и Учитель с большой буквы}

Работы учеников и «учеников учеников» Сергея Ивановича не только отражают стремление отечественного и зарубежного научно-преподавательского сообщества быть в мейнстриме мировой экономической мысли, но и служат доказательством непрерывности и преемственности научного знания, несомненной личной увлеченности общим предметом исследования тех, кого Тюльпанов «поставил на крыло» и кто искренне, серьезно и без притянутого пафоса им восхищался, брал с него пример нравственности и профессионализма.

В октябре 1981 г. на торжественном заседании Ученого совета ЛГУ в благодарственной речи всем поздравившим его с восьмидесятилетием С. И. Тюльпанов прочел стихи «Почти над самым плесом» Александра Андреевича Прокофьева, с которым его связывала многолетняя дружба со времени общей борьбы с фашистами на Ленинградском фронте и блокады Ленинграда. Сергей Иванович развил центральную идею стихотворения, сказав: «Когда я вижу здесь, что бывшие мои студенты и аспиранты стали маститыми докторами наук, заслуженными профессорами, доцентами, то я с таким же чувством глубокого удовлетворения, как А.Прокофьев, думаю, что какая-то часть моей теоретической деятельности и моего отношения к жизни будет ими продолжена, я рад, что “мои деревья меня переживут”. И даже если они забудут “садовника”, это не имеет большого значения» ${ }^{11}$.

Студенты, а впоследствии преподаватели Университета, пришли к выводу, подтвердившемуся в тюльпановской аудитории во время учебы, который помог им в дальнейшем в профессиональной лекторской работе: материал, излагаемый на лекции, вовсе не обязан быть совершенно ясным, разложенным по полочкам; в ней должна пульсировать живая мысль, она должна помогать слушателям творить вместе с лектором, задача которого - пробуждать в студентах жажду знаний и сотворчества.

Тюльпанов вводил молодежь в новый круг логических построений без пустых рассуждений и формальных пауз. Он всегда индивидуально, неповторимо, уникально размышлял о происходящих вокруг изменениях, т. е. о том, что нужно знать любому заинтересованному слушателю. Как ученый, он всегда искал смысл политэкономического, исторического, философского, человеческого, анализируя значение фактов в сфере политики, истории и экономики для развития общества. В революционные времена человек особенно напряженно вглядывается в прошлое, настоящее и будущее, пытаясь угадать, что несет ему время. Опыт поиска истинного смысла явлений и событий предлагает С. И. Тюльпанов и в своих сочинениях.

Суждения С. И. Тюльпанова - это результат устойчивого, целостного видения происходящих событий, и в этом контексте он был искренне предан коммунистической идее, социалистическому строю, будучи уверенным, что капитализм уходит в прошлое. Эта вера естественно вытекала из опыта его жизни. Он помнил Первую мировую войну, был участником Гражданской войны, прошел дорогами Великой Отечественной войны. На его глазах разворачивалась и завершилась антиколониальная борьба народов Азии, Африки, Латинской Америки. Все эти трагические со-

«С.И. Тюльпанов и его школа: вклад в теорию мировой экономики» на конференции «Эволюция международной торговой системы: проблемы и перспективы» 20 октября 2016 г. ЛГУ.

${ }_{11}$ Выступление С. И. Тюльпанова в октябре 1981 г. на торжественном заседании Ученого совета 
бытия были порождением капитализма и колониализма. В большей или меньшей степени война отразилась на судьбах всех членов кафедры, поэтому по идеологическим вопросам у них не могло быть противоречий, все были убеждены, что колесо истории вертится в сторону социализма.

Вера в идею, однако, не сопрягалась у С. И. Тюльпанова с догматизмом. Он анализировал факты реальной жизни, понимая, что жизнь течет, изменяется, появляется новое и отмирает старое. Если факты противоречили сложившимся представлениям, то следовало отдать предпочтение фактам. Курсовые, дипломные работы, статьи, тезисы конференций, диссертации должны быть результатом исследований реальной действительности. Это захватывало молодежь, привлекало внимание к кафедре. Можно сказать, что С. И. Тюльпанов создал школу «реалистической политической экономии» ${ }^{12}$. В 1960-е годы в СССР происходило активное становление двух крупных разделов марксистской экономической науки: политической экономии монополистического капитализма и политической экономии развивающихся стран, и кафедра в этот период стала авторитетным центром по исследованию проблем разных стран и регионов мира. Очень важным элементом политической экономии развивающихся стран была концепция о переходных производственных отношениях, о взаимодействии экономических и политических процессов, взаимосвязи национального хозяйства и мировой экономики ${ }^{13}$. Здесь С. И. Тюльпанов вплотную подошел к институционализму. Преподаватели кафедры читали базовые курсы политической экономии капитализма, курсы по экономике современного капитализма и развивающихся стран (С.И. Тюльпанов, Н. Г. Поспелова), экономике зарубежных стран (А.А. Демин) и экономической истории зарубежных государств (Р. С. Горчаков), проводился спецсемир по «Капиталу»(С. Ф. Михеева).

Практически каждый преподаватель кафедры выносил на суд коллег и учеников оригинальный спецкурс, который был результатом собственных исследований. На кафедре царил дух творчества, каждый старался порадовать коллег и аудиторию собственными разработками. Каждый член кафедры представлял собой яркую личность, все горячо любили свое дело, и студенческая аудитория, как правило, благодарно откликалась на их усилия. Вспоминаются, например, спецкурсы С.И.Тюльпанова и Н.Г.Поспеловой «Актуальные проблемы развивающихся стран»; Н.А. Архипова «Вывоз капитала после Второй мировой войны и обострение империалистических противоречий»; С. Д. Зака «Методологические проблемы развития сельской поземельной общины»; В.Г.Онушкина «Научно-техническая революция и противоречия современного капитализма»; А. А. Демина «Экономика ФРГ: вчера, сегодня, завтра», С.И. Яковлевой «Особенности методов эксплуатации рабочего класса в условиях ГМК»; И. В. Алешиной «Моделирование экономического развития в странах третьего мира»; М.А.Серебровской «Латинская Америка: выбор пути развития»; В. Л. Шейниса «Португальский колониализм в Африке. Эко-

12 Материал выступления Н. В. Раскова «Кафедра экономики современного капитализма: уроки Тюльпанова» на секции 6, посвященной 115 -летию со дня рождения С. И. Тюльпанова «С. И. Тюльпанов и его школа: вклад в теорию мировой экономики», на конференции «Эволюция международной торговой системы: проблемы и перспективы» 20 октября 2016 г.

13 Выступление Л.Д.Широкорада «Идеологический контекст научной и политической деятельности С.И. Тюльпанова» на секции 6, посвященной 115-летию со дня рождения С. И. Тюльпанова «С. И. Тюльпанов и его школа: вклад в теорию мировой экономики», на международной конференции «Эволюция международной торговой системы: проблемы и перспективы» 20 октября 2016 г. 
номические проблемы последней колониальной империи»; Н. С. Бабинцевой «Индустриализация в развивающихся странах»; Ю. В. Пашкуса «Модификация валютно-финансовых отношений современного капитализма»; Н. В. Раскова «Проблемы ГМК: противоречивый механизм действия». У всех преподавателей курсы были основаны на самостоятельных исследованиях, результаты которых обсуждались на кафедре, прежде всего с Сергеем Ивановичем. Он, в свою очередь, всегда поддерживал своих учеников и в предмете, носящем зачастую междисциплинарный характер, и в методах исследования, подчеркивая необходимость использования эконометрических инструментов и расчета длинных статистических рядов динамики. Тюльпанов обращал внимание своих сотрудников не на описательный, а на поисковый, проблемный подход к объекту анализа.

На экономическом факультете ЛГУ на кафедре экономики современного капитализма впервые образовались научно-исследовательские семинары по экономике развивающихся стран (рук.: С.И. Тюльпанов, Н.Г.Поспелова), экономике США и Канады (рук.: В.Г.Онушкин, С.И.Иванов), экономике ФРГ (рук.: А.А.Демин, С. Б. Лавров). В этих семинарах-конференциях принимали участие специалисты по экономике, политологии, истории, философии, психологии со всего Северо-Запада, Ленинграда и других городов и регионов России. Такая форма обучения и повышения квалификации предполагала проведение открытых лекций отечественных и зарубежных ученых, межфакультетских и межуниверситетских дискуссий, обсуждение кандидатских и докторских диссертаций, новых монографий, статей, курсов и спецкурсов. Деятельность этих семинаров представляла настоящий прорыв, так как расширялись горизонты науки, преподавания и жизненной практики, что способствовало формированию нового поколения специалистов ${ }^{14}$.

С. И. Тюльпанов превратил кафедру в центр научной мысли и исследовательского поиска не только отечественного, но и международного значения. Лекции Сергея Ивановича поражали глубиной и неординарностью мысли. В непростых условиях господства идеологических догм Тюльпанов в науке, в жизни, на конференциях, лекциях и семинарах всегда находил слова, доходящие до ума и сердца каждого, к кому он обращался. Тюльпанов относился к тем думающим ученым, которые уходят от упрощенной интерпретации историко-экономического процесса. Можно привести слова великого Арнольда Тойнби, утверждавшего, что идет борьба за влияние на подавляющее большинство человечества, «которое не является ни коммунистическим, ни капиталистическим, ни русским или западным, но живет сейчас в тревожном мире, на ничейной земле между двумя враждующими твердынями противоположных соперничающих идеологий» [Тойнби, 1996]. Это противостояние выступает как духовное противостояние, которое доказывает до сих пор, что жизнь оказывается намного сложнее ожиданий, предсказаний и логики формальных рассуждений. С. И. Тюльпанов хотя и не занимался профессионально в последние десятилетия жизни проблемами социализма, но всегда тяжело переживал неудачи, просчеты и несовершенства коммунистического правления ${ }^{15}$.

14 Выступление М.А.Скляра «Формирование научной школы на кафедре экономики современного капитализма» на секции 6 «С.И. Тюльпанов и его школа: вклад в теорию мировой экономики» на международной конференции «Эволюция международной торговой системы: проблемы и перспективы» 20 октября 2016 г.

15 Выступление В. Л. Шейниса «Сергей Иванович Тюльпанов: его жизнь и современная Россия» конференции «Эволюция международной торговой системы: проблемы и перспективы»; секция 6, 
При всей внешней неприступности, монументальности, уверенности, С.И.Тюльпанов был совершенно открыт и приветлив, выступая как тактичный и умелый руководитель кафедры. Уверенность, которую он демонстрировал в публичных выступлениях, давалась ему непросто, над лекциями, докладами, выступлениями он много работал, переживал, волновался. Он никогда не относился легковесно к своим выступлениям, независимо от того, где они проходили: на кафедре, на международной конференции, перед коллективом факультета или Университета, в студенческой аудитории ${ }^{16}$. Исключительно серьезное отношение к делу, глубокая порядочность, стремление поддержать любое доброе начинание составляли основу его авторитета [Басистов, 2012, с.7].

К сожалению, не всем на экономическом факультете нравились успехи, авторитет, нравственная и научная позиция С.И. Тюльпанова и его руководство кафедрой. Не раз сотрудников кафедры несправедливо обвиняли в идеологической незрелости и политической близорукости. Недруги в конечном счете восторжествовали. Под надуманными предлогами кафедру С.И. Тюльпанова ликвидировали, его сотрудников рассеяли по другим подразделениям факультета [Расков, 2001].

Десятки и сотни учеников С. И. Тюльпанова «выросли в сильные, большие деревья», которые пережили «садовника» и несут дальше знамя его идей, будучи, как Сергей Иванович, свободными личностями, имеющими духовную силу поступать так, как поступает думающая свободная личность, повинуясь собственному представлению о чести и справедливости. Бывшие сотрудники кафедры экономики современного капитализма, его ученики и последователи до сих пор ощущают свою принадлежность школе С. И. Тюльпанова и следуют его урокам [Расков, 2001, с.12-15].

\section{Проект «Политический портрет С. И. Тюльпанова» ${ }^{17}$}

Предполагается издание книги «Политический портрет С.И.Тюльпанова», в которой будет описан его жизненный путь: от молодого красноармейца, активно борющегося с белогвардейцами и интервентами, преподавателя политэкономии в военной академии, офицера, защищавшего Ленинград и Сталинград от фашистов и участвовавшего в освобождении Восточной Европы до известного военно-политического деятеля, крупного ученого Советского Союза в области политической экономии и теории мировой экономики.

посвященная 115-летию со дня рождения С.И. Тюльпанова «С.И. Тюльпанов и его школа: вклад в теорию мировой экономики» на 20 октября 2016 г.

${ }^{16}$ Никогда не забуду одно из последних выступлений С. И. Тюльпанова, посвященное снятию блокады, в начале февраля 1984 г. перед студенческой аудиторией. Он говорил очень просто, описывая страшные факты войны, бомбежек, блокады, смертей. Меня потрясла история, как он шел через замерзшую Неву в Смольный на совещание к Жданову, и впереди него тихо шла замотанная в шубы и платки женщина, которая все время спотыкалась и падала, а он ее поднимал снова и снова. Убывали ее силы и силы опаздывающего в Смольный Сергея Ивановича. Наконец, настал момент, когда в очередной раз она упала и он ее поднял, обогнал и поспешил на работу, зная, что оставляет ее умирать. Эта сила откровенности, человеческого раскаяния, боли и, как я теперь понимаю, прощания потрясла и меня, и всех присутствовавших ребят. Через несколько дней Сергея Ивановича не стало... (прим. авт. - Н.К.)

17 Материал взят из доклада Ингеборг и Михаеля Пардон «Сергей Иванович Тюльпанов - политический портрет» на пленарном заседании конференции «Эволюция международной торговой системы: проблемы и перспективы» 20 октября 2016 г. 
Особое внимание будет уделено деятельности С.И.Тюльпанова, дипломата в военной форме, в составе Советской военной администрации в Германии в послевоенной Германии с 1945 по 1949 г. Именно в этот период С. И. Тюльпанов завоевал глубокое уважение побежденного и в то же время освобожденного от фашизма немецкого народа за помощь в восстановлении немецкой культуры и за ознакомление с русской и советской культурой. «Портрет» должен показать С. И. Тюльпанова - интернационалиста, друга немецкого народа и одного из тех, кто построил особые отношения между народами наших стран в послевоенный период.

В основе книги - обширный материал, собранный в различных архивах, публикации в старых газетах и журналах, свидетельства членов семьи, соратников и сослуживцев С.И. Тюльпанова. Будучи исключительной личностью с необычайной жаждой творчества, он оставил огромное количество различных документов. Удалось собрать и получить от его родственников и коллег солидный фонд. Сергей Сергеевич, младший сын Тюльпанова, открыл архив отца и предоставил официально заверенную доверенность, дающую право на знакомство с различными источниками, хранящимися в российских архивах. Подробные рассказы и воспоминания о жизни и творчестве Сергея Ивановича в личных беседах с членами его семьи, родственниками, друзьями, коллегами дали ответы на вопросы о влиянии семьи на формирование личности, о периоде учения и первых годах работы, о конфликтах, которые приходилось преодолевать.

Особое впечатление произвели на авторов будущей книги беседы с соратниками и близкими друзьями Тюльпанова, например с 93-летним профессором Торкановским и 94-летним профессором Драбкиным, ушедшими из жизни, так и не дождавшись окончания проекта.

В длинном списке собеседников есть и профессор Томас Кучинский, сын Юргена Кучинского, старого немецкого товарища и коллеги Тюльпанова по партийной и научной работе. Немецкие друзья и коллеги, будучи лично знакомы с Сергеем Ивановичем, работали с ним и обогатили проект различными материалами и воспоминаниями. Среди них Эгон Кренц - бывший генеральный секретарь СЕПГ, Ганс Модров - премьер-министр ГДР, бывшие ученики и коллеги Тюльпанова профессора Шютцлер, Прокоп, Рихтер, Шульмайстер и др.

Интересные открытия были сделаны на основании работы с архивными документами. В результате обращения в краеведческий музей Порхова (Псковская обл.) был получен бесценный материал из истории семьи Тюльпановых. Авторы изучили архивные фонды Санкт-Петербургского университета, Ростокского университета, работали в Военно-историческом архиве и Российском центре хранения и изучения документов новейшей истории в Москве, в берлинском архиве немецкой Академии искусств, в Федеральном архиве ФРГ, в котором содержатся обширные архивы политических партий и общественных организаций ГДР и фонда СВАГ.

Занимаясь политико-историческими трудами Тюльпанова - сотрудника СВАГ, можно и сегодня восхититься разнообразием его интересов и четкостью политической позиции. Это, к примеру, статьи, написанные к столетию Коммунистического манифеста, столетию революции 1848 г., 20 июля 1944 г. (покушение на Гитлера); статьи по истории внешней политики Германии и о традициях западноевропейского антикоммунизма и антисоветизма, по истории политических, гражданских партий в Германии, о возникновении новой военной опасности в конце сороковых 
годов, причинах кризиса в партии ХДС 1947/1948 гг., по истории и культуре Советского Союза, о Потсдамском соглашении, немецком реваншизме и милитаризме, странах народной демократии в Восточной Европе, разоблачении деятельности западных спецслужб в советской оккупационной зоне, двухсотлетнем юбилее Гёте в 1949 г., военной и политико-экономической оценке Сталинградской битвы, роли церкви в борьбе за мир, ленинской теории империализма и др.

В трудах Тюльпанова 40-х годов прошлого века представлено удивительно живое и детальное описание послевоенных событий в советской оккупационной зоне. Например, он писал о таком значимом событии, как земельная реформа, о помощи крестьянским хозяйствам и переселенцам, экспроприации имущества военных преступников - нацистов по решению референдума в Саксонии, реформе школьного образования и высшей школы, движении народного конгресса за справедливый мир и единство, за возрождение немецкой культуры и театрального искусства, о возрождении музеев, издательств и кинематографа. Все эти инициативы были бы невозможны без участия широких народных масс только по приказу Советской военной администрации [СВАГ и немецкие органы самоуправления..., 2006]. Наследие Сергея Ивановича включает также обширную переписку с известными советскими и иностранными политиками, учеными, писателями и деятелями искусств, уникальные лекции, интересные интервью и остроумные рецензии, трогательные воспоминания о нем, написанные друзьями и соратниками, великолепные фотографии, свидетельства и документы.

В меньшей степени проект охватывает творчество Сергея Ивановича как известного политэконома с международным именем. Признание, распространение, оценка этого огромного наследия уже в течение многих лет оказываются для его учеников долгом души и сердца, который они готовы выполнить с большой радостью. Авторы готовят популярную публикацию, чтобы как можно больше людей познакомились с этим феноменальным человеком, всю свою жизнь служившим примером для других, о котором В.С. Торкановский сказал: «Если бы такой умный, честный человек, как Тюльпанов, стоял бы после войны во главе Советского государства, то и наша, и мировая история развивались бы иначе...» [Ефимова, Кузнецова, Сутырин, 2002, с.162].

\section{Список важнейших трудов С. И. Тюльпанова}

Тюльпанов С. И., Шейнис В. Л. Актуальные проблемы политической экономии современного капитализма. Л.: Издательство ЛГУ, 1973. 280 с.

Тюльпанов С. И. Возникновение и развитие мирового демократического рынка. Л.: Ленинградское газетно-журнальное и книжное изд-во, 1955. 146 с.

Тюльпанов С. И., Вейи Г. Н. Государственные предприятия Индии // Народы Азии и Африки. 1970. № 3. C. $28-38$.

Тюльпанов С.И. XXIV съезд КПСС о современном этапе национально-освободительной борьбы // Вестн. Ленингр. ун-та. Серия: Экономика. Философия. Право. 1971. Вып. 3. С. 33-42.

Индустриализация Северо-Западного района в годы второй и третьей пятилетки (1933 -1941 гг.): сборник / ред. С. И. Тюльпанов; сост. Н. Н. Амосов [и др.]. Л., 1969. 454 с.

Тюльпанов С.И. Исследование в ЛГУ проблем современного капитализма и развивающихся стран // Вестн. Ленингр. ун-та. Серия: Экономика. Философия. Право. 1969. Вып. 1. С. 25-44.

Тюльпанов С. И. Историческая роль пролетариата в кривом зеркале теоретиков государственно-монополистического капитализма // Вестн. Ленингр. ун-та. Серия: Экономика. Философия. Право. 1975. Вып. 3. С. 14-23. 
Тюльпанов С. И. К вопросу о государственном капитализме в слаборазвитых странах // Вестн. Ленингр. ун-та. Серия: Экономика. Философия. Право. 1961. Вып. 1. С. 5-22.

Тюльпанов С. И. К вопросу о марксистской политической экономии развивающихся стран // Вестн. Ленингр. ун-та. Серия: Экономика. Философия. Право. 1965. Вып. 3. С. 5-17.

Тюльпанов С. И., Шейнис В. Л. Капитализм и проблемы планирования // Вестн. Ленингр. ун-та. Серия: Экономика. Философия. Право. 1971. Вып. 1. С. 19-34.

Тюльпанов С. И. Колониальная система империализма и ее распад. М.: Соцэкгиз, 1958. 258 с.

Тюльпанов С. И., Онушкин В. Г. Кризис мирового капитализма. Л.: Лениздат, 1962. 282 с.

Тюльпанов С. И. Ленинская теория империализма и современный капитализм: материалы временных коллективов // Научная сессия, посвященная 90-летию со дня рождения В. И. Ленина: Тезисы докладов по секции экономических наук. Казанский государственный университет (Казань); Ленинградский государственный университет (Л.). Л., 1960. С. 11-17.

Тюльпанов С.И., Чуфрин Г.И. Некоторые вопросы развития государственного сектора промышленности Индии в период третьего пятилетнего плана // Вестн. Ленингр. ун-та. Серия: Экономика. Философия. Право. 1962. Вып. 3. С. 5-23.

Тюльпанов С. И. О некоторых особенностях государственного капитализма слаборазвитых стран: реферат // Вестн. Ленингр. ун-та. Серия: Экономика. Философия. Право. 1961. Вып. 2. С. 5-26.

Тюльпанов С. И. О переходных категориях в экономике развивающихся стран // Вестн. Ленингр. ун-та. Серия: Экономика. Философия. Право. 1965. Вып. 4. С.25-43.

Тюльпанов С. И. Основной экономический закон современного капитализма: монография. Л.: Лениздат, 1954. $126 \mathrm{c}$

Тюльпанов С. И. Очерки политической экономии. Развивающиеся страны. М.: Мысль, 1969. 375 с.

Тюльпанов С. И. Полезная книга об Африке // Мировая экономика и международные отношения. 1964. № 7. С. 155.

Тюльпанов С.И. Политико-экономические проблемы развивающихся стран: лекции, прочитанные в Ленинградском университете. Л.: Издательство ЛГУ, 1969. 68 с.

Тюльпанов С.И., Вейи Г.М. Проблемы эффективности государственного сектора экономики Индии // Вестн. Ленингр. ун-та. Серия: Экономика. Философия. Право. 1969. Вып. 4. С. 41-50.

Тюльпанов С.И. Проблема нейтрализма слаборазвитых стран в свете решений XXII съезда КПСС // Вестн. Ленингр. ун-та. Серия: Экономика. Философия. Право. 1961. Вып. 4. С. 16-34.

Тюльпанов С.И. Решающий фактор развития освободившихся стран. Рецензия на кн.: Ульрих О.Д. «Третий мир»: проблемы развития государственного сектора // МЭ и МО. 1976. № 4. С. 146-148.

Тюльпанов С. И. 50-летие ленинской теории империализма // Вестн. Ленингр. ун-та. Серия: Экономика. Философия. Право. 1967. Вып. 1. С. 5-24.

Демин А.А., Расков Н.В., Тюльпанов С.И. Современный государственно-монополистический капитализм в свете ленинской теории империализма // Вестн. Ленингр. ун-та. Серия: Экономика. Философия. Право. 1969. Вып. 2. С. 18-34.

Тюльпанов С. И. Сегодня и двадцать пять лет тому назад (к 25-летию СЕПГ) // Вестн. Ленингр. ун-та. Серия: Экономика. Философия. Право. 1971. Вып. 4. С. 18-28.

Тюльпанов С.И. Страны социалистической ориентации против неоколониализма: некоторые аспекты стратегии // Вестн. Ленингр. ун-та. Серия: Экономика. Философия. Право. 1973. № 2. С. 5-21.

Тюльпанов С. И. Ученый-коммунист. К 75-летию со дня рождения А. А. Вознесенского: сб. ст. / под ред. С. И. Тюльпанова. Л.: Изд-во Ленигр. ун-та, 1973.

Тюльпанов С. И. Экономическая функция государства в странах социалистической ориентации // Вестн. Ленингр. ун-та. Серия: Экономика. Философия. Право. 1972. Вып. 3. С. 32-50.

Тюльпанов С.И. Экономические и политические проблемы новых суверенных государств. Л.: Изд-во Ленигр. ун-та, 1964. 165 с.

Тюльпанов С. И., Дадашев Г.А. Экономические проблемы развивающихся стран. Серия: Материалы по политической экономии. М.: Высшая школа, 1967. 118 с.

Тюльпанов С. И. Эксплуатация пролетариата в условиях государственно-монополистического капитализма // Вестн. Ленингр. ун-та. Серия: Экономика. Философия. Право.1975. Вып. 2. С. 35-48.

Tjulpanow S. Das ökonomische Grundgesetz des modernen Kapitalismus. Übersetzung aus dem Russischen. Berlin: Verlag Die Wirtschaft, 1955. 119 S.

Tjulpanow S. I. Entstehung und Entwicklung des sozialistischen Weltwirtschaftssystems. Zu Fragen des 20. Parteitages der KPdSU. Berlin: Verlag Kultur und Fortschritt, 1956. 35 S.

Tjulpanow. Für enge Zusammenarbeit unserer Universitäten // Universitäts-Zeitung Martin-Luther-Universität Halle-Wittenberg. Halle. 26. Juni 1958. S. 3.

Tjulpanow S. Das Kolonialsystem des Imperialismus und sein Zerfall. Berlin: Verlag Die Wirtschaft, 1959. 276 S. 
Tjulpanow S.I. Über einige Besonderheiten des Staatskapitalismus in den schwach entwickelten Ländern // Wissenschaftliche Zeitschrift der Karl-Marx-Universität. Gesellschafts- und sprachwissenschaftliche Reihe. Leipzig. Jg. 11. 1961. Heft 1. S. 103-116.

Tjulpanow S. I. Zur Klassenstruktur der imperialistischen Gesellschaft. Bemerkungen zu einem Aufsatz von Jürgen Kuczynski // Jahrbuch für Wirtschaftsgeschichte. Berlin Jg., 1963. Heft 3. S. 128-135.

Tjulpchrift der Karl-Marx.-Universität. Gesellschafts-und sprachwissenschaftliche Reihe. Leipzig. Jg. 16. 1967. Heft 5. S. 673-679.

Tjulpanow S. I. Probleme des Auslandskapitals in den Entwicklungsländern // Der Außenhandel. Berlin. Jg. 17. 1967. Heft 5.

Tjulpanow S. [u. a.]. Aktuelle Probleme der Entwicklungsländer. Sammelband. Politische Ökonomie, Neokolonialismus, Akkumulationsquellen, Außenwirtschaftsbeziehungen und wirtschaftliches Wachstum. Berlin: Verlag Die Wirtschaft, 1968. 121 S.

Karl Marx „Das Kapital“. Erbe und Verpflichtung. Beiträge zum 100. Jahrestag der Erstausgabe des Werkes „Das Kapital“ von Karl Marx. Im Auftrag der Karl-Marx-Universität Leipzig herausgegeben von A. Heinze und S. I. Tjulpanov. Leipzig: Karl-Marx-Universität, 1968. VIII, 716 S. Kommissionsverlag: Verlag Die Wirtschaft Berlin, 1968.

Tjulpanov Sergej I. Das allgemeine Gesetz der kapitalistischen Akkumuklation und die Lage der Arbeiterklasse. Ebenda. S. 143-169.

Tjulpanow S., Schejnis V. Die Entwicklungsländer in der Weltwirtschaft // Wissenschaftliche Beiträge des Instituts Ökonomik der Entwicklungsländer an der Hochschule für Ökonomie „Bruno Leuschner“ Berlin. Berlin. Jg. 4. 1969. Heft 3. S. 1-93.

Tjulpanow Sergej I. Zur Rolle der Infrastruktur in Entwicklungsländern. In: Wirtschaftswissenschaft. Berlin. Jg. 17. 1969. Heft 9. S. 1373-1394.

Lenins Lehre lebt. Beiträge zum 100. Geburtstag von Wladimir Iljitsch Lenin. Hrsg. von Albrecht Heinze und Sergej I. Tjulpanow. Berlin: Verlag Die Wirtschaft 1970. 396 S.

Tjulpanow S. Zur Frage der sozialen Strategie der Entwicklungsländer. In: Sowjetwissenschaft. Gesellschaftswissenschaftliche Beiträge. Berlin. Jg. 1971. Heft 6. S. 639-650.

Tjulpanow S. I. Politische Ökonomie und ihre Anwendung in den Entwicklungsländern. Übersetzung aus dem Russischen Berlin: Verlag Die Wirtschaft 1975. 429 S.

Tjulpanow S.I. Die ökonomische Funktion des Staates in Ländern mit sozialistischer Orientierung // Wirtschaftswissenschaft. Berlin. Jg. 21. 1973. Heft 11. S. 1674-1690.

Tjulpanow S. Der historische Platz des staatsmonopolistischen Kapitalismus // Sowjetwissenschaft. Gesellschaftswissenschaftliche Beiträge. Berlin. Jg. 26. 1973.Heft 10. S. 1105-1115.

Tjulpanow S.I., Scheinis V.L. Aktuelle Probleme der politischen Ökonomie des heutigen Kapitalismus. Übersetzung aus dem Russischen. Berlin: Verlag Die Wirtschaft 1975. 334 S. [Parallelausgabe:] Frankfurt am Main: Verlag Marxistische Blätter, 1975.

Einheit - im Kampfe geboren. Beiträge zum 30. Jahrestag der Befreiung vom Faschismus. Hrsg. im Auftrag der Karl Marx-Universität Leipzig ... von E[rnstgert] Kalbe und S[ergej] I[vanovich] Tjul'panov. Leipzig: Karl-Marx-Universität, 1975. 219 S.

Tjulpanow Sergej I. Erinnerungen an deutsche Freunde und Genossen. Berlin; Weimar: Aufbau-Verlag, 1984. $162 \mathrm{~S}$.

Tjulpanow Sergej. Deutschland nach dem Kriege (1945-1949). Erinnerungen eines Offiziers der Sowjetarmee. Berlin: Dietz Verlag, 1986. 357 S.

Tulpanow S. Die Rolle der SMAD bei der Demokratisierung Deutschlands // Zeitschrift für Geschichtswissenschaft, 1967. Nr. 2. S. 240-252.

\section{Литература}

Басистов Ю.В. Воспоминания о совместной работе в Германии в первые послевоенные годы // Вестн. С.-Петерб. ун-та. Серия 5. Экономика. Вып. 2. 2012. С. 7-8.

Гибианский Л.Я. Коминформ в зените активности: создание организационной структуры и третье совещание // Совещания Коминформа, 1947, 1948, 1949. Документы и материалы. М.: Российская политическая энциклопедия (РОССПЭН), 1998. С. 509-542.

Драбкин Я.С. Сергей Иванович Тюльпанов и становление послевоенной Германии // Основные тенденции развития мировой экономики: контуры нового тысячелетия: Материалы Международной 
научно-практической конференции, посвященной 100-летию со дня рождения С. И. Тюльпанова. СПб.: Изд-во ОЦЭиМ, 2001. С. 9-10.

Ебимова Е.Г., Кузнецова Н.П., Сутырин С.Ф. Международная конференция, посвященная 100-летию со дня рождения С. И. Тюльпанова // Вестн. С.-Петерб. ун-та. Серия 5. Экономика. 2002. Вып. 1. С. 162-168.

Загадка полковника Сергея Тюльпанова. Пробелы анкетных данных. URL: http://www.//airo-xxi.ru//gb/ statji/tjulpanov.htm (дата обращения: 14.02.2016).

Загадка полковника Сергея Тюльпанова. Московские коридоры власти. URL: www.airo-xxiru/gb/statji/ tjulpanov.htm (дата обращения: 16.03.2016).

История факультета в лицах. URL:/http://www.econ.pu.ru//faculty/history_faculty/history/faces/php/ (дата обращения: 10.11.2016).

История политической экономии. Тюльпанов С.И. URL: http://finlit.online/politicheskoy-ekonomikiistoriya/tyulpanov-7048.html (дата обращения: 24.10.2016).

Протокол первого совещания Коминформа // Совещания Коминформа, 1947, 1948, 1949. Документы и материалы. М.: Российская политическая энциклопедия (РОССПЭН), 1998. С. 52-263.

Расков Н. В. Уроки Тюльпанова // Основные тенденции развития мировой экономики: контуры нового тысячелетия: Материалы Международной научно-практической конференции, посвященной 100-летию со дня рождения С. И. Тюльпанова. СПб.: Изд-во ОЦЭиМ, 2001. С. 12-15.

Семенов В.Н. Александр Алексеевич Вознесенский // Вестн. С.-Петерб. ун-та. Серия 5. Экономика. Вып. 3. 2010. С.3-9.

Скляр М.А. С.И.Тюльпанов - воспитатель научной молодежи // Вестн. С.-Петерб. ун-та. Серия 5. Экономика. 2012. Вып. 2. С. 9-10.

Тойнби А.Дж. Цивилизация перед судом истории / пер с англ. // Современный момент истории. М.: Культура, 1996. С. 263-432.

Торкановский В.С. Воспоминания об учителе и друге // Вестн. С.-Петерб. ун-та. Серия 5. Экономика. 2012. Вып. 2. С.3-6.

Тюльпанов С. И. Воспоминания // Новая и Новейшая история. 1984. № 2, № 4.

Тюльпанов Сергей Иванович. URL: http://ru.wikipedia.org/wiki/ (дата обращения: 12.09.2016).

Шейнис В. Л. Время и судьба ученого. К 90-летию со дня рождения С. И. Тюльпанова // МЭиМО. 1991. № 2. С. $132-144$.

Шейнис В.Л. С.И. Тюльпанов. Время и судьба ученого // Основные тенденции развития мировой экономики: контуры нового тысячелетия: Материалы Международной научно-практической конференции, посвященной 100-летию со дня рождения С. И. Тюльпанова. СПб.: Изд-во ОЦЭиМ, 2001. C. $10-11$.

Электронный каталог. Тюльпанов Сергей Иванович. ABSOPACUnicode. URL: http://libraryuniver.khrakov.ua/ (дата обращения: 30.01.2016).

ABSOPACUnicode. URL: http://libraryuniver.khrakov.ua/(дата обращения: 30.01.2016).

Tjulpanow Sergej. Deutschland nach dem Kriege (1945-1949). Erinnerungen eines Offiziers der Sowjetarmee / ed. by S. Dernberg. Berlin, 1986.

\section{Архивные материалы}

Российский государственный архив социально-политической истории (РГАСПИ). Ф. 17. Оп. 118. Д. 567. Л. $181-182$.

Российский государственный архив социально-политической истории (РГАСПИ). Ф. 17. Оп. 3. Д. 1074. Л. 322, 328.

СВА. Управление пропаганды (информации) и С.И. Тюльпанов. 1945-1949: сб. документов / под ред. Б. Бонвеча, Г. Бордюгова, Н. Неймарка. М., 1994. Д. 1057. Л. 3.

СВАГ. Советская военная администрация в Германии, 1945-1949. Справочник / отв. ред. Я. Фойтцик, Т. В.Царевская-Дякина, А. В. Доронин; при участии Х. Кюнцель, Д.Н. Нохотович. М.: РОССПЭН, 2009.

СВАГ и немецкие органы самоуправления, 1945-1949 / отв. ред. и отв. составитель Н. В. Петров; составители: О. В. Лавинская и Д.Н. Нохотович. М.: РОССПЭН, 2006.

Для цитирования: Кузнецова Н. П., Пардон И., Пардон М. Сергей Иванович Тюльпанов: к 115-летию со дня рождения // Вестник СПбГУ. Экономика. 2017. Т. 33, вып. 1. С. 162-184. DOI: 10.21638/11701/ spbu05.2017.109. 


\section{References}

Basistov Yu. V. Vospominaniia o sovmestnoi rabote v Germanii v pervye poslevoennye gody [Memories of joint work in Germany in the early postwar years]. Vestnik of Saint Petersburg University. Series 5. Economics, 2012, issue 2, pp. 7-8. (in Russian)

Gibianskii L. Ya. [Cominform in the zenith of activity: organizational structure development and the third meeting]. Soveshchaniia Kominforma, 1947, 1948, 1949. Dokumenty i materially [Meetings of Cominform, 1947, 1948, 1949. Documents and Materials]. Moscow, Rossiiskaia politicheskaia entsiklopediia (ROSSPEN), 1998, pp. 509-542. (in Russian)

Drabkin Ya.S. [Sergej Ivanovich Tyulpanov and the formation of post-war Germany]. Osnovnye tendentsii razvitiia mirovoi ekonomiki: kontury novogo tysiacheletiia. Materialy mezhdunarodnoi nauchno-prakticheskoi konferentsii, posviashchennoi 100-letiiu so dnia rozhdeniia S.I.Tiul'panova [Main tendencies of the world economy development: new millennium contours. Paper in the Proceedings of International scientific-practical conference: dedicated to the 100-anniversary of S. I. Tjulpanov]. St. Petersburg, Publ. OTSEiM, 2001, pp.9-10. (in Russian)

Efimova E. G., Kuznetsova N. P., Sutyrin S. F. Mezhdunarodnaia konferentsiia, posviashchennaia 100-letiiu so dnia rozhdeniia S. I. Tiul'panova [International conference dedicated to the 100 -anniversary of S. I. Tjulpanov]. Vestnik of Saint Petersburg University. Series 5. Economics, 2002, issue 1, pp. 162-168. (in Russian)

Zagadka polkovnika Sergeia Tiul'panova. Probely anketnykh dannykh [Colonel Sergei Tyulpanov Riddle. Gaps in personal data]. Available at: http://www.//airo-xxi.ru//gb/statji/tjulpanov.htm (accessed 14.02. 2016). (in Russian)

Zagadka polkovnika Sergeia Tiulpanova. Moskovskie koridory vlasti [Colonel Sergei Tyulpanov Riddle. Moscow corridors of power]. Available at: www.airo-xxiru/gb/statji/tjulpanov.htm (accessed: 16.03.2016). (in Russian)

Istoriia fakul'teta $v$ litsakh [History of the faculty in persons]. Available at: /http://www.econ.pu.ru//faculty/ history_faculty/history/faces/php/ (accessed: 10.11.2016). (in Russian)

Istoriia politicheskoi ekonomii. Tiul'panov S. I. [History of political economy. Tjulpanov S. I.]. Available at: http:// finlit.online/politicheskoy-ekonomiki-istoriya/tyulpanov-7048.html (accessed: 24.10.2016). (in Russian)

[The first Cominform Meeting Minutes]. Soveshchaniia Kominforma, 1947, 1948, 1949. Dokumenty i materially [Meetings of Cominform, 1947, 1948, 1949. Documents and Materials]. Moscow, Rossiiskaia politicheskaia entsiklopediia (ROSSPEN), 1998, pp. 52-263. (in Russian)

Raskov N.V. [Lessons of Tjulpanov]. Osnovnye tendentsii razvitiia mirovoi ekonomiki: kontury novogo tysiacheletiia. Materialy mezhdunarodnoi nauchno-prakticheskoi konferentsii, posviashchennoi 100-letiiu so dnia rozhdeniia S. I. Tiul'panova [Main tendencies of the world economy development: new millennium contours. Paper in the Proceedings of International scientific-practical conference: dedicated to the 100-anniversary of S. I. Tjulpanov]. St. Petersburg, Publ. OTSEiM, 2001, pp. 12-15. (in Russian)

Semenov V.N. Aleksandr Alekseevitch Voznesenskii. Vestnik of Saint Petersburg University. Series 5. Economics, 2010, issue 3, pp. 3-9. (in Russian)

Skliar M. A. S. I. Tul'panov - vospitatel' nauchnoi molodezhi [S. I. Tjulpanov - young generation of researchers tutor]. Vestnik of Saint Petersburg University. Series 5. Economics, 2012, issue 2, pp. 9-10. (in Russian)

Toinbi A. Dzh. [Civilization before the Court of History]. Transl. from engl. Sovremennyi moment istorii [Contemporary moment of History]. Moscow, Kul'tura Publ., 1996, pp. 263-432. (in Russian)

Torkanovskii V.S. Vospominaniia ob uchitele i druge [Memories about the Teacher and Friend]. Vestnik of Saint Petersburg University. Series 5. Economics, 2012, issue 2, pp. 3-6. (in Russian)

Tyulpanov S. I. Vospominaniia [Memories]. Novaia i Noveishaia istiriia [Modern and Current History], 1984, no. 2, 4. (in Russian)

Tyulpanov Sergei Ivanovich. Available at: http://ru.wikipedia.org/wiki/ (accessed: 12.09. 2016). (in Russian)

Sheinis V.L. Vremia i sud'ba uchenogo. K 90-letiiu so dniia rozhdeniia S. I. Tul'panova [Time and Destiny of the scientist. To the 90-th anniversary of S.I. Tjulpanov]. MEiMO, 1991, no. 2, pp. 132-144. (in Russian)

Sheinis V. L. [S. I. Tjulpanov. Time and Destiny of the scientist]. Osnovnye tendentsii razvitiia mirovoi ekonomiki: kontury novogo tysiacheletiia. Materialy mezhdunarodnoi nauchno-prakticheskoi konferentsii, posviashchennoi 100-letiiu so dnia rozhdeniia S. I. Tiul'panova [Main tendencies of the world economy development: new millennium contours. Paper in the Proceedings of International scientific-practical conference: dedicated to the 100-anniversary of S. I. Tjulpanov]. St. Petersburg, Publ. OTSEiM, 2001, pp.10-11. (in Russian)

Elektronnyi katalog. Tiul'panov Sergei Ivanovich [Digital catalogue. Tjulpanov Sergej Ivanovitch]. ABSOPACU nicode. Available at: http://libraryuniver.khrakov.ua/ (accessed: 30.01.2016). (in Russian)

ABSOPACUnicode. Available at: http://libraryuniver.khrakov.ua/ (accessed: 30.01.2016). 
Tjulpanow Sergej. Deutschland nach dem Kriege (1945-1949). Erinnerungen eines Offiziers der Sowjetarmee. Ed by S. Dernberg. Berlin, 1986.

For citation: Kuznetsova N. P., Pardon I., Pardon M. Sergey Ivanovitch Tyulpanov: The 115 anniversary of birthday. St Petersburg University Journal of Economic Studies, 2017, vol. 33, issue 1, pp. 162-184. DOI: 10.21638/11701/spbu05.2017.109.

Статья поступила в редакцию 1 декабря 2016 г. Статья рекомендована в печать 19 января 2017 г. 